\title{
Correction to: Merzifon-Esençay splay fault within the North Anatolian Fault system: segmentation and timing of the last two surface faulting events on Esençay segment
}

\author{
Ömer Emre ${ }^{1} \cdot$ Hasan Elmacı ${ }^{2} \cdot$ Selim Özalp ${ }^{2} \cdot$ Ediz Kırman $^{1}$
}

Published online: 3 December 2020

(c) Springer Nature Switzerland AG 2020

\section{Correction to: Mediterranean Geoscience Reviews (2020) https://doi.org/10.1007/s42990-020-00040-7}

The authors regret and apologise that the final version of the article does not have the correct caption of Fig. 2, and hereby we would like to provide the proper caption below:

Fig. 2 Map showing regional pattern of splay faults bifurcating from the NAF and seismicity in north-Central Anatolia. Faults from Emre et al. (2013); instrumental data from Kadirioğlu et al. (2018); historical earthquakes from Tan et al. (2008).

\section{References}

Kadirioğlu FT, Kartal RF, Kılıç T, Kalafat D, Duman TY, Eroğlu Azak T, Özalp S, Emre Ö (2018) An improved earthquake catalogue $(\mathrm{M} \geq 4.0)$ for Turkey and its near vicinity (1900-2012). Bull Earthq Eng 16(8):3317-3338. https://doi.org/10.1007/s 1051 8-016-0064-8

Tan O, Tapırdamaz C, Yörük A (2008) The earthquake catalogues for Turkey. Turk J Earth Sci 17:405-418

The original article can be found online at https://doi.org/10.1007/ s42990-020-00040-7.

Ömer Emre

o.emre@fugro.com

1 Fugro Sial Geosciences Consulting and Engineering, Farabi Sok. 40/4, 06680 Ankara, Turkey

2 General Directorate of Mineral Research and Exploration (MTA), Department of Geological Research, 06800 Ankara, Turkey 